\title{
Plant intraspecific competition and growth stage alter carbon and nitrogen mineralization in the rhizosphere
}

\author{
Yue Sun ${ }^{1,2}$ ( ) | Huadong Zang ${ }^{3}$ | Thomas Splettstößer ${ }^{4}$ | Amit Kumar ${ }^{5}$ | \\ Xingliang $\mathrm{Xu}^{6}$ | Yakov Kuzyakov ${ }^{2,4,7}$ | Johanna Pausch ${ }^{1}$
}

\author{
${ }^{1}$ Department of Agroecology, BayCEER, \\ University of Bayreuth, Bayreuth, Germany \\ ${ }^{2}$ Department of Agricultural Soil Science, \\ University of Göttingen, Göttingen, Germany \\ ${ }^{3}$ College of Agronomy and Biotechnology, \\ China Agricultural University, Beijing, China \\ ${ }^{4}$ Department of Soil Science of Temperate and \\ Boreal Ecosystems, University of Göttingen, \\ Göttingen, Germany \\ ${ }^{5}$ Chair of Ecosystem Functioning and Services, \\ Institute of Ecology, Leuphana University of \\ Lüneburg, Lüneburg, Germany \\ ${ }^{6}$ Key Laboratory of Ecosystem Network \\ Observation and Modelling, Institute of \\ Geographic Sciences and Natural Resources \\ Research, CAS, Beijing, China \\ ${ }^{7}$ Peoples Friendship University of Russia \\ (RUDN University), Moscow, Russian \\ Federation

\section{Correspondence} \\ Yue Sun, Department of Agroecology, \\ BayCEER, University of Bayreuth, 95447 \\ Bayreuth, Germany. \\ Email: yue.sun@uni-bayreuth.de \\ Funding information \\ Deutsche Forschungsgemeinschaft, Grant/ \\ Award Number: project PA 2377/2-1; RUDN \\ University, Grant/Award Number: program \\ 5-100; Russian Science Foundation, Grant/ \\ Award Number: 19-77-30012
}

\begin{abstract}
Plant roots interact with rhizosphere microorganisms to accelerate soil organic matter (SOM) mineralization for nutrient acquisition. Root-mediated changes in SOM mineralization largely depend on root-derived carbon (root-C) input and soil nutrient status. Hence, intraspecific competition over plant development and spatiotemporal variability in the root- $\mathrm{C}$ input and nutrients uptake may modify SOM mineralization. To investigate the effect of intraspecific competition on SOM mineralization at three growth stages (heading, flowering, and ripening), we grew maize (C4 plant) under three planting densities on a C3 soil and determined in situ soil C- and $\mathrm{N}$ mineralization by ${ }^{13} \mathrm{C}$-natural abundance and ${ }^{15} \mathrm{~N}$-pool dilution approaches. From heading to ripening, soil $\mathrm{C}$ - and $\mathrm{N}$-mineralization rates exhibit similar unimodal trends and were tightly coupled. The $\mathrm{C}$-to-N-mineralization ratio (0.6 to 2.6 ) increased with $\mathrm{N}$ availability, indicating that an increase in $\mathrm{N}$-mineralization with $\mathrm{N}$ depletion was driven by microorganisms mining $\mathrm{N}$-rich SOM. With the intraspecific competition, plants increased specific root lengths as an efficient strategy to compete for resources. Root morphologic traits rather than root biomass per se were positively related to $\mathrm{C}$ - and $\mathrm{N}$-mineralization. Overall, plant phenology and intraspecific competition controlled the intensity and mechanisms of soil $\mathrm{C}$ - and $\mathrm{N}$ - mineralization by the adaptation of root traits and nutrient mining.
\end{abstract}

\section{KEYWORDS}

${ }^{13} \mathrm{C}$ natural abundance, ${ }^{15} \mathrm{~N}$ pool dilution, arable soil, carbon and nitrogen mineralization, intraspecific competition, maize, root traits, soil organic matter decomposition

\section{1 | INTRODUCTION}

The coexistence of organisms in unfertilized soils is characterized by strong competition for nutrients between plant communities and between plant roots and microorganisms (Adler et al., 2018; Kuzyakov \& Xu, 2013; Moreau et al., 2015). Soil organic matter (SOM) is a major reservoir of essential nutrients required for plant growth, but the availability of these nutrients, notably nitrogen $(N)$, largely relies on microbial mediated transformation. Hence, microbial $\mathrm{N}$ mineralization from SOM and subsequent immobilization/nitrification are crucial processes determining the intrinsic $\mathrm{N}$ supply of soil for plant productivity in natural and agroecosystems (Tiessen, Cuevas, \& Chacon, 1994). The microbially driven processes can be significantly regulated by plant roots, as root-derived inputs of labile organic

This is an open access article under the terms of the Creative Commons Attribution License, which permits use, distribution and reproduction in any medium, 
compounds (i.e., rhizodeposits) fuel the activity and growth of heterotrophic microorganisms (Cheng \& Kuzyakov, 2005; Paterson, 2003). This, in turn, stimulates the synthesis of extracellular enzymes to mine for nutrients necessary for microbial growth, causing the acceleration of SOM mineralization (microbial $\mathrm{N}$ mining hypothesis; Craine, Morrow, \& Fierer, 2007). As a result, microbial N mineralization and immobilization tend to increase (Ehtesham \& Bengtson, 2017; Murphy, Baggs, Morley, Wall, \& Paterson, 2015; Zhu et al., 2014). Although microorganisms are the superior competitor for $\mathrm{N}$ in a short term, the faster turnover of microbial biomass (hours to days) than that of roots (weeks to months) may lead to the release of microbial immobilized $\mathrm{N}$ to soil, facilitating plant $\mathrm{N}$ uptake over the long term (Dijkstra, Bader, Johnson, \& Cheng, 2009; Frank \& Groffman, 2009; Kuzyakov \& $\mathrm{Xu}, 2013)$. Such root-mediated changes in SOM mineralization have increasingly been recognized as a nutrient acquisition strategy of plants to exchange carbon (C) to soil microorganisms for $\mathrm{N}$ and other nutrients (Kuzyakov \& Xu, 2013). To consider the processes by which plant roots govern SOM turnover has far-reaching implications for understanding plant-microbial-soil interactions in terrestrial ecosystems.

Mechanistic explanations for root-mediated changes in SOM mineralization often point to interactive effects of belowground $C$ input by roots and soil nutrient availability, which are strongly influenced by plant growth stages and plant-plant interactions (Cheng et al., 2014; Huo, Luo, \& Cheng, 2017). The assimilates allocation and storage belowground reflect specific strategies of plants for growth and vary with their growth stages (Nguyen, 2003; Pausch \& Kuzyakov, 2018). Plant development impacts the amount and composition of rhizodeposits, as the relative contribution of root exudates and residues to rhizodeposition differs greatly between plant growth stages (Amos \& Walters, 2006). Moreover, the spatial and temporal dynamics of root physiological and morphological traits, such as root biomass (Dijkstra \& Cheng, 2007), root exudates (Zhu \& Cheng, 2012), root architecture and morphology (Pausch et al., 2016) may regulate the rhizosphere effects on SOM turnover over plant development. Alterations of root traits depend to a large extent on the plant performance (i.e., photosynthesis) (Bardgett, Bowman, Kaufmann, \& Schmidt, 2005), and thus on controlling factors such as light, nutrient, and water (Craine, Wedin, Chapin, \& Reich, 2003; Kuzyakov et al., 2002; Sanaullah, Chabbi, Rumpel, \& Kuzyakov, 2012). Concurrently, plant-associated changes in the soil environment, for example, the availability of $C$ and nutrients, as well as physical and chemical soil properties, that is, water, $\mathrm{pH}$ values, and soil aggregation may also modify the microbial function and SOM mineralization (Jenkinson \& Rayner, 1977; Shields, Paul, Lowe, \& Parkinson, 1973).

Plant-plant interactions often impose interspecific and intraspecific competition for above and belowground resources, that is, light and nutrients. However, the effect of plant-plant interactions on soil $\mathrm{C}$ and $\mathrm{N}$ turnover through rhizospheric processes remains uncertain, as contradictory results have been shown previously (Fan, Zhang, \& Lu, 2011; Pausch, Zhu, Kuzyakov, \& Cheng, 2013; Yin, Dijkstra, Wang, Zhu, \& Cheng, 2018). A plant may increase $C$ allocation to roots and adapt root morphological traits that enhance individual competitive capacity relative to their neighbors for nutrient uptake, thereby potentially enhancing the $\mathrm{C}-\mathrm{N}$ exchanges and SOM mineralization (Kunstler et al., 2016; Schenk, 2006; Sun et al., 2020; Tilman, 1990). In contrast, it has been previously reported that SOM mineralization can be suppressed under the interspecific (Dijkstra, Morgan, Blumenthal, \& Follett, 2010; Pausch et al., 2013) and intraspecific competition (Yin et al., 2018). These negative effects are explained by the nutrient competition hypothesis (Dormaar, 1990; Kuzyakov, 2002), which suggests that strong competition for nutrients between roots and microorganisms may inhibit microbial activity for decomposing SOM due to a limitation of nutrients. In addition to belowground resources, plants with denser canopies may compete for light. Such aboveground competition may indirectly influence the SOM turnover, by affecting photosynthetic capacity as well as the photosynthates allocated belowground (Aerts, 1999; Wang et al., 2020). Of the several studies that have examined the effects of plant competition on SOM turnover, most were conducted under controlled conditions with a restricted soil volume for nutrient uptake by plants (Dijkstra et al., 2010; Pausch et al., 2013; Schofield et al., 2019; Wang et al., 2020; Yin et al., 2018). The direct estimation of plant competition on SOM mineralization and the relevance of microbial mechanisms under field conditions remain elusive.

In natural ecosystems, the microbial activation by roots and subsequent mining for $\mathrm{N}$ from SOM has been identified to be an essential driver for the coupling of $C$ and $N$ turnover of soils (Finzi et al., 2015; Phillips, Finzi, \& Bernhardt, 2011). However, conventional agriculture often assumes that the $\mathrm{N}$ supply from SOM mineralization is inadequate to meet the $\mathrm{N}$ demands of plants, especially for crops with a high $\mathrm{N}$ uptake rate, for example, maize (Zea mays) (Loecke, Cambardella, \& Liebman, 2012; Osterholz, Rinot, Liebman, \& Castellano, 2017). Thus, maize has received much more $\mathrm{N}$-fertilizers (mean rate of $136 \mathrm{~kg} \mathrm{~N} \mathrm{ha}^{-1}$ ) than other crops worldwide (FAO, 2006). Intensive fertilization may reduce the reliance of plant $\mathrm{N}$-uptake on $\mathrm{N}$ mineralization, causing the potential decoupling of soil $\mathrm{C}$ and $\mathrm{N}$ cycling (Drinkwater \& Snapp, 2007). Although it is essential in the context of fertilization management in the agroecosystem, very few studies examined the processes by which roots regulate SOM decomposition and $N$ mineralization in the agriculture field (Francis et al., 2003; Spiertz, 2010).

Therefore, this study aims to investigate how plants control the coupling between $\mathrm{C}$-input and SOM turnover for nutrient uptake in an arable soil under field conditions, with a focus on assessing the effects of plant intraspecific competition on soil $\mathrm{C}$ and $\mathrm{N}$ mineralization at different plant growth stages. Experimental trials were established with varying plant densities. We grew maize (C4 plants) with three planting densities for 132 days on a C3 soil (C3-to-C4 vegetation change; Kumar, Kuzyakov, \& Pausch, 2016). The ${ }^{13} \mathrm{C}$ natural abundance approach was used to partition total $\mathrm{CO}_{2}$ efflux for SOMderived $\mathrm{CO}_{2}$ and root-derived $\mathrm{CO}_{2}$, and in situ ${ }^{15} \mathrm{~N}$ pool dilution approach was applied to quantify gross $\mathrm{N}$ transformation. Soil and microbial properties, and root morphological changes were measured concurrently in maize at three different growth stages (heading, flowering and maize ripening). We hypothesize that (a) root-mediated changes in soil $\mathrm{C}$ and $\mathrm{N}$ mineralization vary with maize growth stages, 
due to a strong variation of $\mathrm{C}$ input by roots into the soil and the gradually decreasing soil $\mathrm{N}$ content through plant uptake; (b) root mediated changes in SOM decomposition are associated with $N$ mineralization during plant growth because of microbial activation by roots for $\mathrm{N}$ mining, and (c) the modulation of soil $\mathrm{C}$ and $\mathrm{N}$ mineralization by intraspecific competition depends on the root traits for nutrient uptake and the soil mineral $\mathrm{N}$ status.

\section{2 | MATERIALS AND METHODS}

\section{1 | Study site}

The experiment was conducted on an agricultural field at the "Reinshof" research station of the Georg-August University of Göttingen $\left(51^{\circ} 29^{\prime} 37.2^{\prime \prime} \mathrm{N}\right.$ and $\left.9^{\circ} 55^{\prime} 36.9^{\prime \prime} \mathrm{E}\right)$. The study area has a temperate oceanic climate with an annual mean temperature of $8.5^{\circ} \mathrm{C}$ and mean precipitation of $850 \mathrm{~mm}$. The meteorological data during the experimental monitoring period are shown in Figure S1. The soil is classified as a Haplic Luisol with a silty loam texture (74.9\% silt, 3.2\% sand, $21.9 \%$ clay) (Berger, 1999). It contains $1.41 \pm 0.04 \%$ total $C$ and $0.16 \pm 0.002 \%$ total $\mathrm{N}$ and has a bulk density of about $1.3 \mathrm{~g} \mathrm{~cm}^{-3}$ from $0-35 \mathrm{~cm}$ depth and a pH of 6.2 (Kumar, Dorodnikov, Splettstößer, Kuzyakov, \& Pausch, 2017; Mason-Jones, Schmücker, \& Kuzyakov, 2018). The organic $C$ at the site originated from permanent C3 vegetation $\left(\delta^{13} \mathrm{C}\right.$ of soil $=-26.1 \%$ ). To separate root-derived $\mathrm{C}$ from SOM-derived $\mathrm{C}$, a vegetation change from $\mathrm{C}_{3}$ to $\mathrm{C}_{4}$ crop (maize; Zea mays L. cv. Colisee; $\delta^{13} \mathrm{C}$ of maize $=-13.3 \%$ ) was applied. This allowed introducing a distinct ${ }^{13} \mathrm{C}$ signal into the soil with a difference in $\delta^{13} \mathrm{C}$ values between soil and plant of $\sim 12 \%$ (Cheng, Johnson, \& $\mathrm{Fu}, 2003)$.

\subsection{Experimental setup}

Sixteen experimental plots (each with an area of $5 \times 5 \mathrm{~m}$ ) were aligned in 4 rows in the field, each with 2-m wide buffer strips to exclude the neighboring effects. A gradient of plant densities was established following a random design, with 4 replicates each: (a) a plant density of 6 plants $\mathrm{m}^{-2}$ as the control (P); (b) a double plant density of 10 plants $\mathrm{m}^{-2}$ (DP), which is equivalent to the normal maize planting density for conventional farming in Germany; (c) a triple plant density of 16 plants $\mathrm{m}^{-2}$ (TP). Additionally, four plots were kept free from vegetation as bare fallow.

In planted plots, maize seeds were firstly sown in 10 rows and 40 plants per row, with a density of 15 plants $\mathrm{m}^{-2}$. They were manually thinned to the respective low and double plant density 30 days after planting (DAP). Before maize sowing, conventional tillage practices were operated up to $30 \mathrm{~cm}$ of soil depth and all plots received phosphorus $\left(\mathrm{P}_{2} \mathrm{O}_{5}\right)$ and potassium $\left(\mathrm{K}_{2} \mathrm{O}\right)$ fertilizers. Temperature sensors (32 PT-100 sensors, OTOM Group $\mathrm{GmbH}$, Germany) were installed at $10 \mathrm{~cm}$ depth to monitor soil temperature. Soil moisture (0-10 cm depth) was measured by $6 \mathrm{ECH} 2 \mathrm{O} \mathrm{EC}-5$ moisture sensors (decagon devices). Hourly air temperature and atmospheric pressure were collected from the weather station of the German Weather Service in Geismar, Göttingen.

\section{3 | Sampling and analyses}

\subsection{1 | Plant and soil sampling}

Plants and soil were sampled at 72, 102, and 132 days after planting. While sampling soil and plants, we avoided the first 2-3 maize rows to take care of edge effects at each sampling campaign. The shoots of the plants were sampled randomly from each plot and weighed after oven-drying at $60^{\circ} \mathrm{C}$. Since the roots of maize plants are mainly concentrated in the upper $30 \mathrm{~cm}$ (Amos \& Walters, 2006), soils and roots were collected together by soil cores $(\sim 7 \mathrm{~cm}$ diameter) from four soil depths at $0-5 \mathrm{~cm}, 5-15 \mathrm{~cm}, 15-25 \mathrm{~cm}$ and $25-35 \mathrm{~cm}$ between two maize rows in the middle of the diagonal between two plants. In the lab, root samples were separated from soils by sieving and were washed. Roots were then scanned on a flatbed scanner and analyzed for morphological traits (WinRhizo, Regent Instruments Inc., Quebec City, Canada). After scanning, the roots were dried at $60^{\circ} \mathrm{C}$ for 48 hours and weighed.

Microbial biomass $\mathrm{C}(\mathrm{MBC})$ and microbial biomass $\mathrm{N}(\mathrm{MBN})$ were determined for all depths at each of the three sampling times by the chloroform fumigation-extraction method with modifications (Vance, Brookes, \& Jenkinson, 1987). Briefly, $8 \mathrm{~g}$ of fresh soil was extracted with $40 \mathrm{~mL}$ of $0.05 \mathrm{M} \mathrm{K}_{2} \mathrm{SO}_{4}$ after shaking for 60 min on a reciprocating shaker (Laboratory shaker, GFL 3016) and the filtrates were measured for total extractable $\mathrm{C}$ and $\mathrm{N}$ with a multi $\mathrm{C} / \mathrm{N}$ analyzer (multi C/N analyzer 2100S, Analytik, Jena). The same extraction procedure was used for fumigated soil, which was fumigated with ethanol-free $\mathrm{CHCl}_{3}$ at room temperature for $24 \mathrm{hr}$. Extractable organic $\mathrm{C}$ and $\mathrm{N}$ of non-fumigated soil were used as a measure of dissolved organic $C$ (DOC) and dissolved N (DN). MBC and MBN were calculated as a difference of total extractable organic $\mathrm{C}$ and $\mathrm{N}$ between fumigated and non-fumigated samples using the extraction efficiency of 0.45 and 0.54 for $M B C$ and $M B N$, respectively (Joergensen \& Mueller, 1996). Additionally, $10 \mathrm{~g}$ soil of each core was oven-dried at $105^{\circ} \mathrm{C}$ for $24 \mathrm{~h}$ to determine the gravimetric water content.

\subsection{2 | Respiration measurements}

From July to late October 2015 , soil $\mathrm{CO}_{2}$ efflux was measured in situ using pre-installed soil chambers at 54, 74, 90, 102, 122, 132 days after the planting. In the central zone of each plot, a vented static chamber made of polyvinyl chloride (area $0.05 \mathrm{~m}^{2}$ and approx. $14.5 \mathrm{~L}$ total volume) was inserted $\sim 2 \mathrm{~cm}$ into the soil between two maize rows for the entire measurement period. Concurrently, $20 \mathrm{~mL}$ gas samples were collected at 20-min intervals using a syringe and stored in pre-evacuated exetainer vials with rubber septa (Exetainer; Labco 
Limited, Lampeter, UK) and analyzed for the $\delta^{13} \mathrm{C}$ of $\mathrm{CO}_{2}$ using an isotope ratio mass spectrometer (IRMS) (Finnigan Delta plus XP, Thermo Electron Corporation, Germany).

\subsection{3 | Gross $\mathrm{N}$ mineralization and nitrification}

Gross rates of $\mathrm{N}$ mineralization and nitrification were measured in situ three times at 74, 102, and 132 days' after planting, which corresponds to the heading, flowering and ripening stages of maize $(\mathrm{BBCH}$ Monograph, 2001). The ${ }^{15} \mathrm{~N}$ pool dilution approach by intact soil cores was used to estimate gross $\mathrm{N}$ mineralization (GNM) and gross nitrification rates (GNN) (Davidson, Hart, Shanks, \& Firestone, 1991). In the central zone of each plot, between two maize rows, five intact soil cores in proximity to one another $\left(5 \mathrm{~cm}\right.$ high with a volume of $\left.251.2 \mathrm{~cm}^{3}\right)$ were taken: $\mathrm{NH}_{4}{ }^{+}$was applied as $\mathrm{NH}_{4} \mathrm{Cl}$ solution with a mixture of $0.6 \mu \mathrm{g}$ ${ }^{15} \mathrm{~N} \mathrm{~g}^{-1}$ soil (99 atom\% ${ }^{13} \mathrm{C}$, Sigma Aldrich) and $2.4 \mu \mathrm{g}{ }^{14} \mathrm{~N} \mathrm{~g}^{-1}$ soil to two of the five cores for determining gross $\mathrm{N}$ mineralization; $\mathrm{NO}_{3}{ }^{-}$ was applied as $\mathrm{KNO}_{3}$ solution with a mixture of $0.6 \mu \mathrm{g}{ }^{15} \mathrm{~N} \mathrm{~g}^{-1}$ soil (99 atom\% ${ }^{13} \mathrm{C}$, Sigma Aldrich) and $2.4 \mu \mathrm{g}{ }^{14} \mathrm{~N} \mathrm{~g}^{-1}$ soil to another two cores to determine gross nitrification. Water was added to the remaining cores for measuring the initial level of $\mathrm{NH}_{4}{ }^{+}$and $\mathrm{NO}_{3}{ }^{-}$. The ${ }^{15} \mathrm{~N}$ enrichment for ${ }^{15} \mathrm{NH}_{4} \mathrm{Cl}$ (or $\mathrm{K}^{15} \mathrm{NO}_{3}$ ) solutions was 20 atom\%. One of each set of cores was well mixed and extracted 10 minutes after ${ }^{15} \mathrm{~N}$ labeling directly in the field (TO soil cores), the remaining cores from each pair were extracted after $24 \mathrm{hr}$ of incubation at room temperature (T1 soil cores). Briefly, $80 \mathrm{~g}$ soil from each core was extracted with $210 \mathrm{~mL}$ of $0.05 \mathrm{~mol} \mathrm{~L}^{-1} \mathrm{~K}_{2} \mathrm{SO}_{4}$ after shaking for $60 \mathrm{~min}$ on a reciprocating shaker (Laboratory shaker, GFL 3016). The concentrations of $\mathrm{NO}_{3}{ }^{-}$and exchangeable $\mathrm{NH}_{4}{ }^{+}$in extracts were measured with a continuous flow analyzer (Skalar Analytical, Breda, Netherlands). Then, the ${ }^{15} \mathrm{~N}$ enrichment of $\mathrm{NH}_{4}{ }^{+}$and $\mathrm{NO}_{3}{ }^{-}$were determined by IRMS (Finnigan Delta plus XP, Thermo Electron Corporation, Germany) following the diffusion procedures (Murphy et al., 2003).

\section{$2.4 \quad$ Calculations and statistics}

Soil $\mathrm{CO}_{2}$ efflux rates were calculated as the slope of linear regressions describing the change in $\mathrm{CO}_{2}$ concentration in the chamber headspace over time and were adjusted to field-measured air temperature and pressure during measurement. We used Keeling-Plots (Miller \& Tans, 2003) to calculate the $\delta^{13} \mathrm{C}$ values of pure soil $\mathrm{CO}_{2}$ without the admixture of atmospheric $\mathrm{CO}_{2}$. Afterward, total $\mathrm{CO}_{2}$ efflux $\left(C_{\text {Total }}\right)$ was partitioned into SOM-derived $\mathrm{CO}_{2}\left(C_{\text {SOM }}\right)$ and root-derived $\mathrm{CO}_{2}\left(C_{\mathrm{Root}}\right)$ using a two-source isotopic mixing model (Phillips \& Gregg, 2001):

$$
\begin{gathered}
C_{\text {SOM }}=C_{\text {Total }}\left(\delta^{13} C_{\text {Root }}-\delta^{13} C_{\text {Total }}\right) /\left(\delta^{13} C_{\text {Root }}-\delta^{13} C_{\text {SOM }}\right) \\
C_{\text {Root }}=C_{\text {Total }}-C_{\text {SOM }}
\end{gathered}
$$

where $\delta^{13} C_{\text {Root }}$ is the $\delta^{13} \mathrm{C}$ value of roots. Note that the differences in $\delta^{13} \mathrm{C}(\%)$ between the root and root-derived $\mathrm{CO}_{2}$ of maize possibly ranged from -4.50 to $-0.20 \%$ as reported previously (Werth \& Kuzyakov, 2010; Zhu \& Cheng, 2011a); future work must measure and account for the ${ }^{13} \mathrm{C}$ isotopic fractionation at different growth stages. $\delta^{13} \mathrm{C}_{\mathrm{T} \text { otal }}$ is the measured $\delta^{13} \mathrm{C}$ value of total soil $\mathrm{CO}_{2}$ efflux and $\delta^{13} \mathrm{C}_{\text {som }}$ is the average $\delta^{13} \mathrm{C}$ value of soil $\mathrm{CO}_{2}$ measured in the bare fallow using Keeling-Plots (Miller \& Tans, 2003).

Furthermore, specific root-derived $\mathrm{CO}_{2}$ was calculated by dividing root-derived $\mathrm{CO}_{2}$ by root biomass. Gross $\mathrm{N}$ mineralization and gross nitrification were calculated following the equations in (Davidson et al., 1991; Sun, Schleuss, Pausch, Xu, \& Kuzyakov, 2018). Specific root length (SRL) was calculated as total root length per root dry weight and specific root area (SRA) as root surface area per root dry weight. Specific SOM-C and $\mathrm{N}$ mineralization rates were calculated by dividing SOM-derived $\mathrm{CO}_{2}$ and gross $\mathrm{N}$ mineralization by total root length, respectively.

To assess the potential intensity of the shoot and root competition, we use the modified version of relative competition intensity (RCl) according to (Callaway et al., 2002):

$$
\mathrm{RCl}=(X \mathrm{c}-\mathrm{Xt}) / x,
$$

where $\mathrm{Xc}$ and $\mathrm{Xt}$ is the shoot biomass (or root biomass, $\mathrm{g} \mathrm{m}^{-2}$ ) in the control $(P)$ and density treatments (DP and TP), respectively, and $x$ is the highest value of $\left(X_{c}: X t\right)$. Positive $\mathrm{RCl}$ value denotes competition.

\subsection{Statistical analysis}

The experiment was conducted with 4 field replicates. Normality (Shapiro-Wilk test, $p>.05$ ) and homogeneity of variance (Levene test, $p>.05)$ were examined and data were log-transformed before analysis if necessary. For soil-associated variables (Figure 1, 2b and Figure S5; Table 2 and Table S2), ANOVA was used with plant growth stages (i.e., comparing different stages for each planting density) and/or planting density (i.e., comparing density treatments for each growth stage) as the fixed factors as well as the interaction between plant growth stages and density treatments. Since soil temperature and moisture may strongly influence soil $\mathrm{C}$ and $\mathrm{N}$ cycling in the presence of roots (Table S1; Zhu \& Cheng, 2011b, 2013), we included soil temperature and soil water content (measured in situ at 74, 102 and 132 DAP) as covariates. Inclusion of covariates accounted for any masking effect of variations in soil temperature and soil moisture on the measured soil variables among density treatments and across plant growth stages. Other than the effects of plant growth stages, planting density and their interactions on the plant-associated variables were assessed using ANOVA, where soil temperature and moisture were not included as covariates (Figure 2a, Table 1 and Table S3). A one-tailed $t$-test was used to assess the significances between $\mathrm{RCl}$ and zero (Table 1). All statistical analyses were performed with SPSS 22 , with the significance level at $p<.05$. Simple regressions were used to identify relationships between response variables with significances at $p<.05$. 
FIGURE 1 Total $\mathrm{CO}_{2}$ efflux (a), root-derived (b), and SOM-derived $\mathrm{CO}_{2}$ efflux (c), and gross $\mathrm{N}$ mineralization (GNM; d) (bars show means $\pm S E$; $n=4$ ) for the single (P), double (DP) and triple (TP) densities at the heading, flowering, and ripening stages. Significant differences $(p<.05)$ between growth stages for each planting density are presented by different uppercase letters, while lowercase letters indicate significant differences between three planting densities at each growth stage [Colour figure can be viewed at wileyonlinelibrary.com]

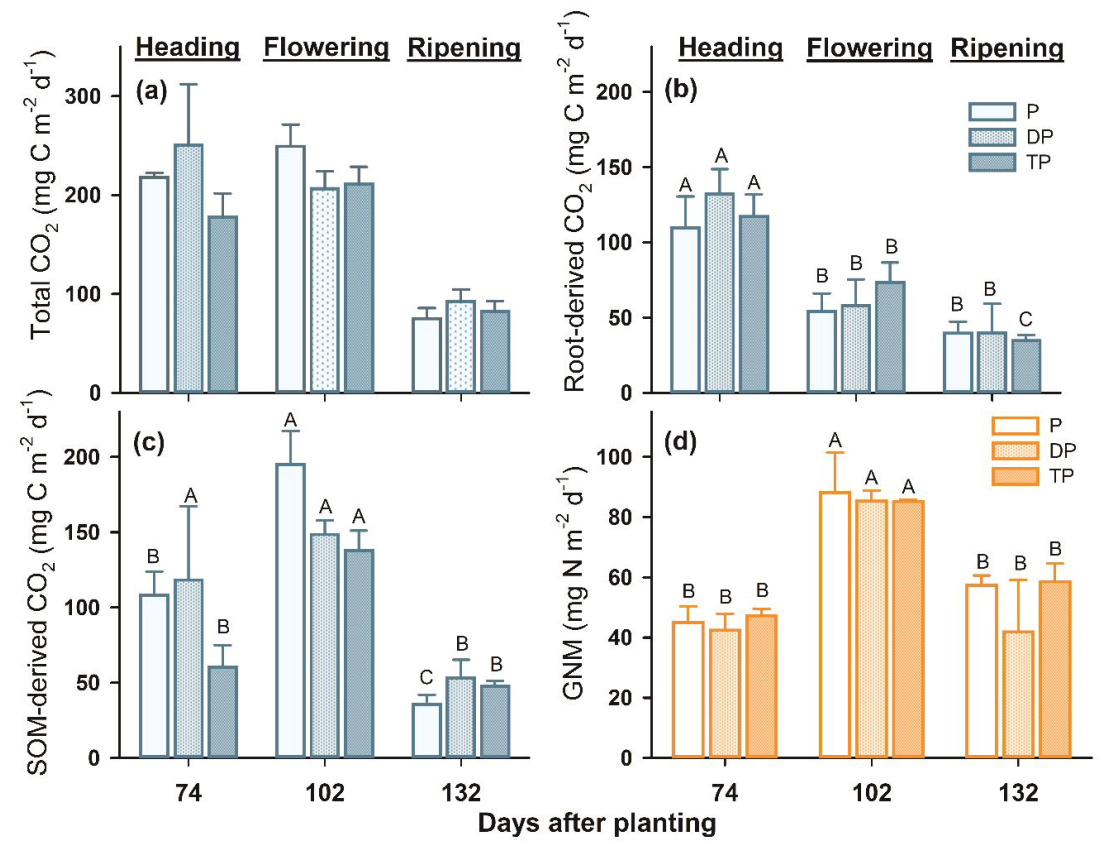

\section{3 | RESULTS}

\section{1 | Plant biomass and root morphology}

The shoot biomass per $\mathrm{m}^{-2}$ increased from maize heading to ripening stages. Root biomass per $\mathrm{m}^{-2}$ remained unchanged with growth stages for the single and double densities, but it increased for the triple density (Table 1 and Table S3). For each growth stage, maize produced a similar shoot and root biomass in total at the double and triple densities, which were higher than that at the single density (Table 1 and Table S3). However, both shoot and root biomass decreased after normalizing for plant density at double and triple densities. These results were consistent with the positive relative competition intensity $(\mathrm{RCl})$ of shoot and root (Table 1 and Table S3). For either double or triple density, a higher belowground intraspecific competition (as indicated by the $\mathrm{RCl}$ of root) reached at flowering. The $\mathrm{RCl}$ of root at the triple density was higher than that at the double density (Table 1 and Table S3) and was negatively correlated to soil mineral $N$ contents $\left(R^{2}=0.6\right.$, $p=.03$; Figure S2a).

At the heading and ripening stages, root length per unit of root biomass (specific root length; SRL) was similar among the planting densities, but the SRL at maize flowering stage increased by $46 \%$ and $49 \%$ at the double and triple densities, respectively (as compared with single density, $p<.05$; Figure 2a). Moreover, SRL increased with the $\mathrm{RCl}$ of root for maize at both double $\left(R^{2}=0.7, p<.001\right)$ and triple densities $\left(R^{2}=0.4, p=.05\right)$ (Figure S2b). Root surface area per unit of root biomass (specific root surface area; SRA) remained similar for each planting density throughout growth stages. Average fine root diameters (AFRD; in the upper $35 \mathrm{~cm}$ soil) slightly decreased with growth stages and were lower at higher planting densities (Table 1 and Table S3).

\subsection{Fluxes and sources of $\mathrm{CO}_{2}$}

Total $\mathrm{CO}_{2}$ efflux ranged from 75 to $251 \mathrm{mg} \mathrm{C} \mathrm{m}^{-2}$ day $^{-1}$. It remained similar at the heading and flowering stages and then decreased by $64 \%$ at maize ripening (Figure 1a). However, none of the main and interactive effects of plant growth stages and planting density was statistically significant ( $p>.05$, Table S2) when considering soil temperature and moisture as covariates. The contributions of root- and SOM-derived sources to total $\mathrm{CO}_{2}$ efflux were similar between the planting densities but were dependent on maize growth stages. The root-derived $\mathrm{CO}_{2}$ on average contributed $56 \%, 28 \%$ and $46 \%$ to the total $\mathrm{CO}_{2}$ at heading, flowering, and ripening stages, respectively (across planting density; Figure $1 \mathrm{a}$ and b). Root-derived $\mathrm{CO}_{2}$ efflux significantly decreased from the heading to ripening (ranged from 39.8 to $135 \mathrm{mg} \mathrm{C} \mathrm{m}^{-2}$ day $^{-1}$ ) independently of the plant density (Figure $1 \mathrm{~b}$ ). Root-derived $\mathrm{CO}_{2}$ per unit of root biomass (specific rootderived $\mathrm{CO}_{2}$ ) declined with maize growth stages. The double and triple densities led to lower specific root-derived $\mathrm{CO}_{2}$ efflux compared to the single density at the heading and flowering stages (Figure 2b). SOM-derived $\mathrm{CO}_{2}$ efflux was higher at the flowering stage, followed by the heading and ripening stages for all levels of plant densities (ranged from 35.5 to $195.1 \mathrm{mg} \mathrm{C} \mathrm{m}^{-2}$ day $^{-1}$, Figure 1c). Yet, the planting density had a minor effect on SOM-derived $\mathrm{CO}_{2}$ efflux for each growth stage (Figure 1c). When considering SOM-derived $\mathrm{CO}_{2}$ efflux per unit root length (specific SOM-C mineralization), however, higher plant densities led to the lower rates of specific SOM-C mineralization for each growth stage (Figure $5 \mathrm{~S}$ and Table S2). Since the $\delta^{13} \mathrm{C}$ value 


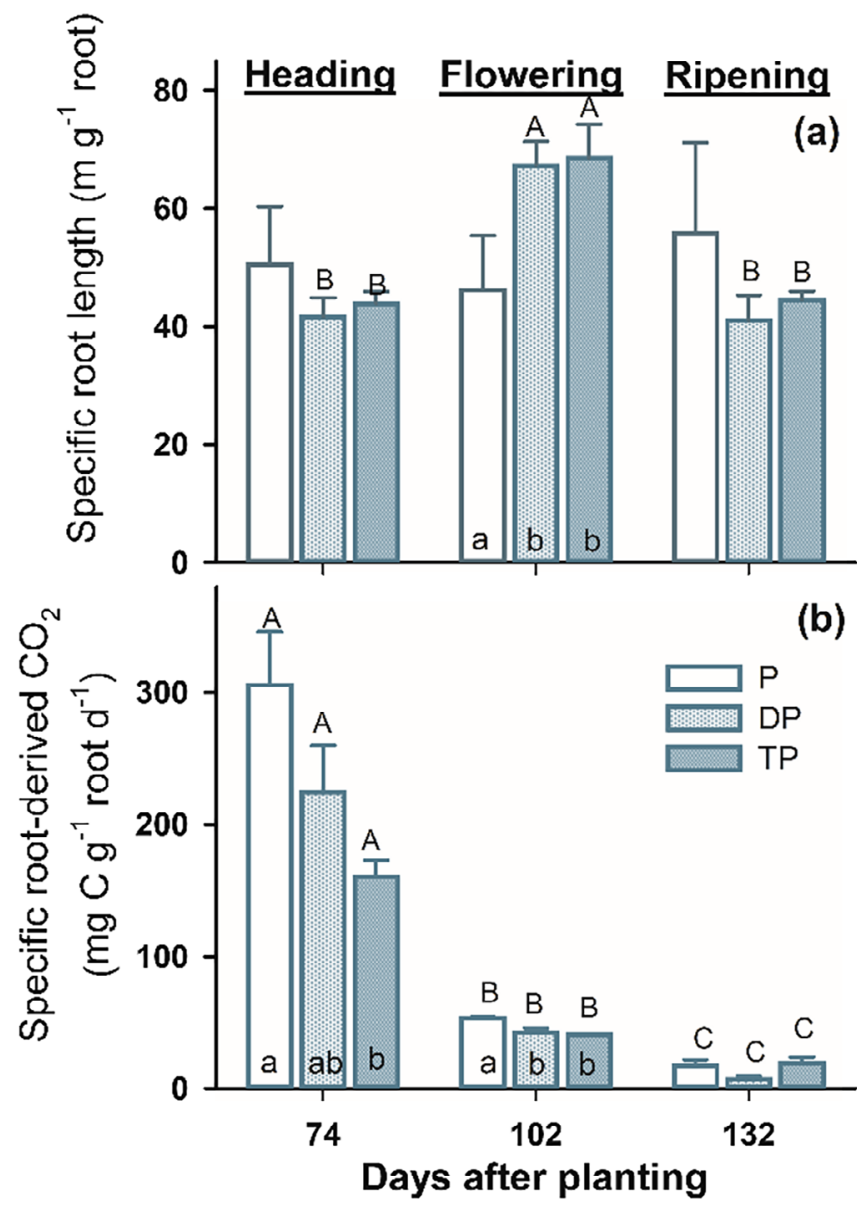

FIGURE 2 Specific root length (a) and specific root- $\mathrm{CO}_{2}$ efflux (b) for the single (P), double (DP), and triple (TP) densities at maize heading, flowering and ripening stages (bars show means $\pm S E ; n=4$ ). Significant differences $(p<.05)$ between growth stages for each planting density are presented by uppercase letters, while lowercase letters indicate significant differences between three planting densities at each growth stage [Colour figure can be viewed at wileyonlinelibrary.com] of roots were used for the $\delta^{13} \mathrm{C}$ value of root-derived $\mathrm{CO}_{2}$ without accounting for ${ }^{13} \mathrm{C}$-depletion in rhizosphere respiration relative to the root, our results may slightly underestimate root-derived $\mathrm{CO}_{2}$ efflux and overestimate $\mathrm{SOM}$-derived $\mathrm{CO}_{2}$ efflux.

\subsection{Soil N mineralization and nitrification}

Plant growth stage, but not the planting density exerted significant control over gross $\mathrm{N}$ mineralization (GNM), which varied between 41.9 and $88.2 \mathrm{mg} \mathrm{N} \mathrm{m}^{-2}$ day $^{-1}$ (Figure 1d). The rates of GNM remained similar at maize heading and ripening stages across all planting densities, while a higher rate of GNM occurred at flowering. Likewise, there was no difference between the planting densities in gross nitrification (GNN) and the higher GNN at the flowering stage compared to other stages (Table 2). The GNN rates at the heading and flowering stages were higher than the rates of GNM. There was a decreasing trend for specific GNM (GNM per unit of root length) with increasing planting densities, though the differences were statistically significant (Figure S5 and Table S2). Mineral $\mathrm{N}$ contents (exchangeable $\mathrm{NH}_{4}{ }^{+}$plus $\mathrm{NO}_{3}{ }^{-}$) decreased with maize growth by $40 \%$ at the flowering and $30 \%$ at ripening as compared with heading stages on average (across overall planting densities; Table 2).

\subsection{Soil $\mathrm{C}$ and $\mathrm{N}$ content and microbial biomass}

Dissolved N (DN) contents in soil decreased with maize growth. For each growth stage, the double and triple densities led to similar DN contents, which were approximately 1.7 times lower than that at the single density $(p<.05$; Table 2). Dissolved organic C (DOC) contents remained similar at the heading and ripening but decreased at maize

TAB LE 1 Plant shoot and root biomass, relative competition intensity (RCI) of the shoot and root, specific root surface area (SRA), and average fine root diameter (AFRD) depending on the plant growth stage and planting density.

\begin{tabular}{|c|c|c|c|c|c|c|c|}
\hline Growth stages & Density & \multicolumn{2}{|c|}{ Biomass $\mathrm{kg}^{-1} \mathrm{~m}^{-2}$} & \multicolumn{2}{|l|}{$\mathrm{RCl}$} & $\frac{\text { SRA }}{m^{-2} g^{-1}}$ & $\frac{\text { AFRD }}{\mathrm{mm}}$ \\
\hline Heading & $\mathrm{P}$ & $0.4(0.05) b$ & $0.01(0.002) b$ & & & $0.06(0.01)$ & $0.38(0.02) \mathrm{b}$ \\
\hline \multirow[t]{2}{*}{74 DAP } & DP & $0.6(0.04) a$ & $0.03(0.002) a$ & $0.1(0.05) b^{*}$ & $0.02(0.02) \mathrm{b}$ & $0.06(0.01)$ & $0.42(0.001) a$ \\
\hline & TP & $0.7(0.05) a$ & $0.02(0.001) a$ & $0.3(0.05) a^{*}$ & $0.46(0.02) a^{*}$ & $0.05(0.001)$ & $0.38(0.01) \mathrm{b}$ \\
\hline Flowering & $\mathrm{P}$ & $1.1(0.2) b$ & $0.02(0.001)$ & & & $0.05(0.01)$ & $0.35(0.01) a$ \\
\hline 102 DAP & TP & $1.6(0.2) \mathrm{a}$ & $0.03(0.004)$ & $0.5(0.06)^{*}$ & $0.53(0.06)^{*}$ & $0.07(0.001)$ & $0.32(0.02) a b$ \\
\hline Ripening & $\mathrm{P}$ & $1.5(0.1) b$ & $0.02(0.001) b$ & & & $0.05(0.02)$ & $0.33(0.01)$ \\
\hline \multirow[t]{2}{*}{132 DAP } & $\mathrm{DP}$ & $2.3(0.3) a$ & $0.03(0.003) a b$ & $0.2(0.07) b^{*}$ & $0.28(0.08)^{*}$ & $0.04(0.003)$ & $0.3(0.01)$ \\
\hline & TP & $1.9(0.2) a b$ & $0.03(0.004) a$ & $0.6(0.04) a^{*}$ & $0.40(0.09)^{*}$ & $0.04(0.001)$ & $0.28(0.01)$ \\
\hline
\end{tabular}

Note: Data are means with standard errors $(n=4)$ except for shoot biomass where $n=8$. Root-associated variables are considered 0-35 $\mathrm{cm}$ of soil depth. Significant differences among three planting densities at each plant growth stages are denoted by different letters (post hoc Tukey-Kramer honest test, $p<.05)$. RCl of the shoot and root values significantly larger than zero in the double and triple densities are presented as * (one-tailed $t$-test, $p<.05$ ). 
TAB LE 2 Gross nitrification (GNN), total dissolved organic C (DOC) and dissolved N (DN), microbial biomass C (MBC) and N (MBN), mineral $\mathrm{N}$ (exchangeable $\mathrm{NH}_{4}{ }^{+}$plus $\mathrm{NO}_{3}{ }^{-}$), the ratio of SOM-C and $\mathrm{N}$ mineralization (SOM-derived $\mathrm{CO}_{2}$ : GNM) for the single (P), double (DP), and triple (TP) densities at three growth stages

\begin{tabular}{|c|c|c|c|c|c|c|c|c|}
\hline Growth stages & Density & $\frac{G N N}{m g ~ N ~ ~ m^{-2} d-1}$ & $\frac{\mathrm{DOC}}{\mathrm{g} \mathrm{C}^{-2}}$ & MBC & $\begin{array}{l}\mathrm{DN} \\
\mathrm{g} \mathrm{N} \mathrm{m}^{-2}\end{array}$ & MBN & Mineral $\mathrm{N}$ & $\frac{\mathrm{SOM}-\mathrm{C} \text { to } \mathrm{N}}{\text { mineralization }}$ \\
\hline Heading & $\mathrm{P}$ & $110.1(54.1)$ & $14.1(0.5)$ & $47.9(2.9) \mathrm{c}$ & $6.4(0.7) a$ & $11.6(1.0)$ & $2.1(0.1) a$ & $2.6(0.6)$ \\
\hline 74 DAP & $\mathrm{TP}$ & $133.3(46.4)$ & $15(0.7)$ & $55.2(0.5) \mathrm{b}$ & $3.8(0.1) b$ & $12.3(1.0)$ & $1.9(0.1) b$ & $1.3(0.4)$ \\
\hline Flowering & $\mathrm{P}$ & $274.1(125.3)$ & $13.7(0.8)$ & 75.1 (1.9) & $5.7(0.5) a$ & $12.1(0.7) b$ & $0.8(0.1)$ & $2.3(0.2) a$ \\
\hline 102 DAP & TP & $170.4(46.0)$ & $13.3(0.3)$ & 75 (1.6) & $3.8(0.3) b$ & $13.7(0.5) a b$ & $1.1(0.1)$ & $1.6(0.2) b$ \\
\hline Ripening & $\mathrm{P}$ & $-36.7(28.0)$ & $17.4(0.01)$ & $75.2(3.9) b$ & $4.9(0.6) a$ & $12.1(0.3)$ & $1.2(0.1)$ & $0.6(0.1) b$ \\
\hline \multirow[t]{2}{*}{ 132DAP } & DP & $-51.4(27.6)$ & $17.4(0.8)$ & 77.2 (3.6)ab & $3.9(0.2) b$ & $12.2(1.4)$ & $1.1(0.3)$ & $1.1(0.2) a$ \\
\hline & $\mathrm{TP}$ & $-1.8(24.4)$ & $18.1(0.8)$ & $89.6(4.0) a$ & $2.9(0.1) b$ & $13.8(0.7)$ & $1.0(0.1)$ & $0.8(0.1) a b$ \\
\hline
\end{tabular}

Note: Data are means with standard errors $(n=4)$. GMN, GNN, and mineral $N$ are considered $0-5 \mathrm{~cm}$ soil depth, while DOC, DN, MBC, and MBN are considered 0-35 cm soil depth. Significant differences among three planting densities at each plant growth stages are denoted by different letters (post hoc Tukey-Kramer honest test, $p<.05)$.

FIGURE 3 Linear relationship between $\mathrm{SOM}$-derived $\mathrm{CO}_{2}$ efflux and gross $\mathrm{N}$ mineralization (GNM) (a) $(n=36)$. A linear relationship between the SOM-C to $\mathrm{N}$ mineralization rate (the ratios of SOM-derived $\mathrm{CO}_{2}$ and $\mathrm{GNM}$ ) and total dissolved $\mathrm{N}(\mathrm{DN})(\mathrm{b})(n=36)$. Data for (a) and (b) include the single (P), double (DP) and triple (TP) densities across all three growth stages [Colour figure can be viewed at wileyonlinelibrary.com]
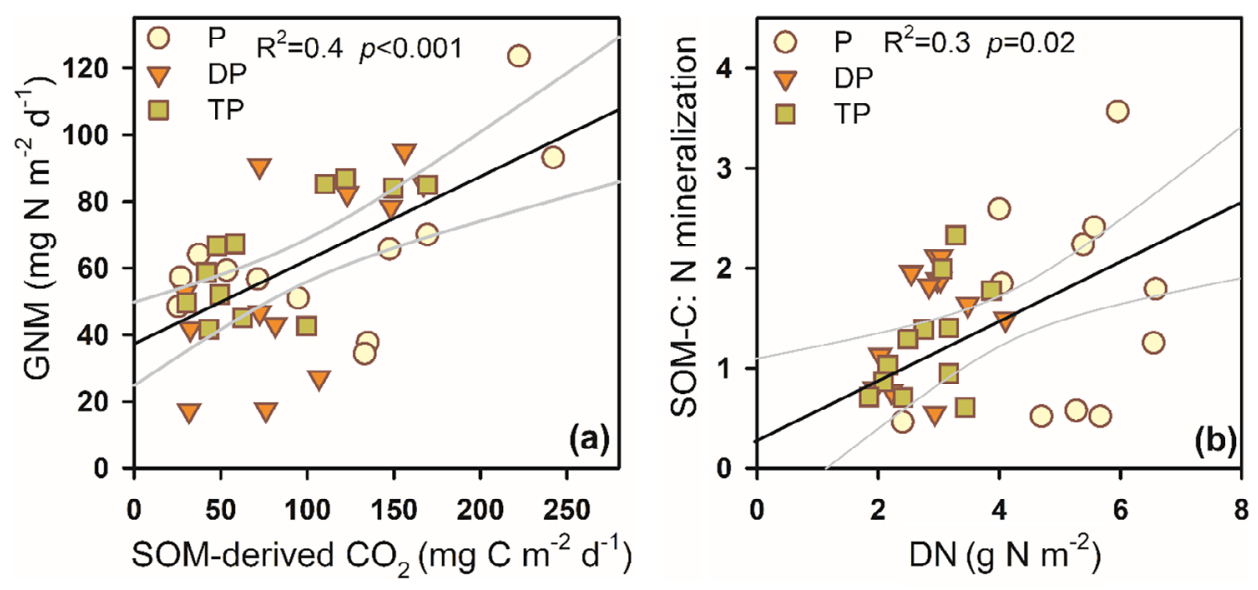

flowering (Table 2). Microbial biomass $C$ (MBC) gradually increased from the heading to ripening stages. The observed increase was up to $57 \%, 12 \%$ and $62 \%$ at the single, double and triple densities, respectively, while microbial biomass $N(M B N)$ was independent of maize growth (Table 2).

\subsection{Relationships between soil C and N mineralization}

There was a positive linear relation between SOM-derived $\mathrm{CO}_{2}$ and GNM across all planting densities $\left(\mathrm{R}^{2}=0.4, p<.04\right.$; Figure 3a). The C: $\mathrm{N}$ ratio of SOM mineralization (the ratio between SOM-derived $\mathrm{CO}_{2}$ and GNM) declined with growth stages, and it was reduced with increased planting densities compared to the single density at the earlier two growth stages (Table 2). Moreover, the C:N ratio of SOM mineralization increased with soil DN content $\left(r^{2}=0.3, p=.02\right.$; Figure 3b). SOM-derived $\mathrm{CO}_{2}$ and GNM were independent of root biomass and specific root-derived $\mathrm{CO}_{2}$ efflux (Figure S3). However, both SOM-derived $\mathrm{CO}_{2}$ and $\mathrm{GNM}$ increased with specific root length for the double and triple densities (Figure $3 a$ and $b$ ).

\section{4 | DISCUSSION}

\subsection{Rhizosphere effects on soil C and N mineralization depend on plant phenology}

For all levels of plant densities, the SOM-C and $\mathrm{N}$ mineralization showed similar unimodal patterns throughout maize growth stages and peaked at flowering (Figure 1c). This indicates that plant growth stages exert an important control on the dynamic of soil $\mathrm{C}$ and $\mathrm{N}$, as similarly reported by earlier studies on maize (Kumar, Shahbaz, Blagodatskaya, Kuzyakov, \& Pausch, 2018; Li et al., 2017) and other crops (Cheng et al., 2003; Pausch et al., 2013; Zhu et al., 2018). The phenology-dependent effect on $\mathrm{C}$ and $\mathrm{N}$ fluxes from SOM is plausibly 
explained by plant-microbial interactions that are driven by (a) root growth and altered quality and quantity of rhizodeposits and, (b) changes in root morphological traits with growth stages, and (c) plant-associated changes in soil properties and nutrient status.

While root biomass remained almost constant from the heading to ripening stages (across all planting densities; Table 1), root-derived $\mathrm{CO}_{2}$ efflux strongly declined (Figure $1 \mathrm{~b}$ ), even after normalization for root biomass (specific root-derived $\mathrm{CO}_{2}$, Figure $2 \mathrm{~b}$ ). This indicates the decreased root respiration and indirectly alludes to a reduction of the quantity of rhizodeposits with maize growth. A major reason for this could be that annual crops allocate more $C$ belowground during the early phases of vegetation stages. Whereas the newly assimilated $C$ remains in aboveground tissues for producing biomass and cobs at later growth stages, despite the increased shoots likely producing more photo-assimilated C (Chen, Palta, Wu, \& Siddique, 2019; Gregory \& Atwell, 1991; Pausch \& Kuzyakov, 2018). This down-regulated $\mathrm{C}$ translocation from shoots to roots from heading to maize ripening is indicated by a negative relationship between root-derived $\mathrm{CO}_{2}$ efflux and shoot biomass (Figure S4a).

At the maize heading stage, the higher root-mediated $C$ release (as indicated by root-derived $\mathrm{CO}_{2}$; Figure $1 \mathrm{~b}$ and $2 \mathrm{~b}$ ) is coincident with the relatively abundant mineral $\mathrm{N}$ in soil (Table 2). The microbial growth and activity may be promoted with a better supply of $C$ and nutrients sources (Hessen et al., 2004). This condition, however, favors microbial community to directly utilize easily degradable rhizodeposits over recalcitrant SOM for $\mathrm{C}$ and energy requirements (preferential substrate utilization, Hagedorn, Spinnler, \& Siegwolf, 2003; Blagodatskaya, Yuyukina, Blagodatsky, \& Kuzyakov, 2011). This is indicated by the much larger contributions of root-derived $\mathrm{CO}_{2}$ to total $\mathrm{CO}_{2}$ efflux (> $50 \%$ of total $\mathrm{CO}_{2}$ efflux) at the heading rather than at the other two stages, with consequent lower SOM mineralization (for all planting densities, Figure 1c). Likewise, microorganisms might preferably assimilate the available $\mathrm{N}$ source and thus decreased $\mathrm{N}$ mineralization. Therefore, preferential substrates utilized by microorganisms result in the lower gross $\mathrm{C}$ and $\mathrm{N}$ fluxes from SOM at earlier developmental stages in comparison with subsequent growth stages.

The SOM-C and $\mathrm{N}$ mineralization rates were highest at maize flowering, though root-derived $C$ inputs decreased substantially (Figure $1 \mathrm{~b}$ and $2 \mathrm{~b}$ ) with a simultaneous decline of soil available $\mathrm{N}$ (DN and mineral $\mathrm{N}$ contents, Table 2). One mechanistic explanation for the enhanced SOM-C and $\mathrm{N}$ mineralization could be that the microbial community accelerates SOM mineralization to mine for $\mathrm{N}$ (Craine et al., 2007; Sun et al., 2018). The accelerated gross $\mathrm{N}$ mineralization released additional ammonium further resulted in higher gross nitrification at the flowering (Table 1). Moreover, SOM-C mineralization was accompanied by slight increases in $\mathrm{MBC}$ and a significant reduction in DOC contents (for all levels of planting densities; Table 2). Hence, the SOM-derived $\mathrm{CO}_{2}$ cannot be mostly originated from microbial overflow respiration and accelerated microbial turnover. Regardless of the reduced root-derived C supply, microbial communities likely have switched to the consumption of available dissolved $C$ in the soil to maintain their functionality to mineralize SOM (Blagodatskaya et al., 2014). Another explanation could be that the maize at the flowering stage has adapted root morphology, that is, longer root length, thinner root diameter and larger root surface areas on average, which potentially improved microbial mineralization for $\mathrm{N}$ mining (section 4.2. Figure 2a, Table 1).

At the maize ripening stage, the relative lower SOM-C and $\mathrm{N}$ mineralization were likely due to the biotic and abiotic factors that constrain microbial activity. Root-mediated microbial activation was possibly inhibited because of the very low inputs of root-derived $C$ after maize maturity (Figure $1 \mathrm{~b}$ and $2 \mathrm{~b}$ ). This is supported by our studies showing that the stimulating effect of roots on the activities of $\mathrm{C}$-, $\mathrm{N}$ - and $\mathrm{P}$-acquiring enzymes were lower at maize maturity compared to the earlier stages (Kumar et al., 2018). Due to the depletion of soil available $\mathrm{N}$ (Table 2), the intensified plant-microbial competition for $\mathrm{N}$ could suppress microbial activity and hence SOM mineralization (Kuzyakov \& Xu, 2013). Furthermore, abiotic environmental conditions such as cooler temperature, have affected microbial activity and turnover directly (Price \& Sowers, 2004), but may also alter plant-microbial interactions through changes in plant activity (e.g., photosynthetic activity, transpiration and nutrient uptake) (Nord \& Lynch, 2009), with respective feedbacks for microbial processes.

Taken together, SOM-C mineralization positively related to gross $\mathrm{N}$ mineralization throughout maize growth (across all planting densities; Figure 3a), which agree with previous studies on grassland and forest soils (Bengtson, Barker, \& Grayston, 2012; Dijkstra et al., 2009; Phillips et al., 2011). This indicates that soil $C$ and $N$ cycles are tightly coupled in this arable soil. Furthermore, the $\mathrm{C}$-to- $\mathrm{N}$ mineralization ratios of SOM tend to increase with soil DN contents (Figure $3 b$ ), which suggests that the intensity of $\mathrm{N}$-fluxes associated with SOM mineralization was dependent on microbial $\mathrm{N}$ availability. When soil mineral $\mathrm{N}$ was depleted by plant $\mathrm{N}$ uptake (as suggested by a negative relationship between plant biomass and soil mineral N, Figure S4b), microorganisms likely acted much more on specific $\mathrm{N}$-rich components of the heterogeneous SOM to mine $\mathrm{N}$ contained within (Murphy et al., 2015). We, therefore, conclude that the microbial $\mathrm{N}$ mining hypothesis underlies the coupled turnover of $\mathrm{C}$ and $\mathrm{N}$ in this arable soil across plant growth stages.

\section{2 | Rhizosphere effects on soil $\mathrm{C}$ and $\mathrm{N}$ mineralization depend on intraspecific competition}

Competition occurs when plant growth and nutrition are constrained by neighbors as a result of the reduction in above- or belowground resources, such as light, water, and nutrients (Aerts, 1999; Colom \& Baucom, 2019). Given the positive relative competition intensity $(\mathrm{RCl})$ of shoots and roots (Table 1 ), the double and triple densities induced intensive above- and belowground intraspecific competition throughout maize growth stages. In light of microbial activation by living roots (Blagodatskaya et al., 2014; Cheng \& Kuzyakov, 2005; Kumar et al., 2016), the increase in root biomass at higher planting densities are expected to enhance microbial decomposition (Table 1). However, planting density did not affect the root-derived $\mathrm{CO}_{2}$ efflux, and the SOM-C and $\mathrm{N}$ 
mineralization (when comparing one growth stage, Figure 1). Also, neither SOM-C nor $\mathrm{N}$ mineralization showed a clear relationship with root biomass and root-derived $\mathrm{CO}_{2}$ efflux (across plant growth stages; Figure S3). This is inconsistent with earlier studies suggesting that the stimulation of microbial decomposition by roots is dependent on the root biomass and the quantity of rhizodeposits (e.g., Bengtson et al., 2012; Dijkstra, Cheng, \& Johnson, 2006; Shahzad et al., 2015; Wang et al., 2015; Yin et al., 2018). Here, a possible reason is that maize at higher densities expressed other root traits such as morphological traits in regulating SOM decomposition because of intraspecific competition.

Previous studies have proposed that plants can shape roots with an efficient morphological structure, such as high specific root length, high branching intensity and low diameter to compete for belowground resources (Sun et al., 2020; Valverde-Barrantes, Smemo, \& Blackwood, 2015). The intraspecific competition belowground is more intensive at maize flowering (Table 1), as similarly shown by other maize fields (Li et al., 2019). Rather than producing more roots and exudates (as indicated by decreased specific root-derived $\mathrm{CO}_{2}$; Figure $2 \mathrm{~b}$ ), maize at higher planting densities altered morphological traits towards thinner and longer roots per biomass unit at the flowering stage (as indicated by lower average fine root diameters and higher specific root lengths at the double and triple densities; Figure 2a, Table 1 and Table S3). In view of the root economics spectrum (Ma et al., 2018; Valverde-Barrantes et al., 2015), the decrease in root diameter may increase the efficiency of root growth and thus enhance root length to explore temporal and spatial available resources (Kuzyakov \& Xu, 2013; Ma et al., 2018; Wen, Li, Shen, \& Rengel, 2017). Accordingly, specific root length increased with belowground intraspecific competition ( $\mathrm{RCl}$ of roots) and increasing planting densities (Figure S2b), which is in agreement with previous studies (Kumar et al., 2020; Li et al., 2019). Furthermore, soil $\mathrm{C}$ and $\mathrm{N}$ turnover were modulated by root morphological traits at higher planting densities, since both SOM-C and $\mathrm{N}$ mineralization increased with specific root length for the double and triple densities (Figure 4). Here, we suggest two possible effects of root morphology in regulating SOM decomposition. First, higher specific root length enables roots to occupy a considerably larger soil volume, and the increased surfacearea-to-volume ratios may largely extend the distribution of rhizodeposits, which fuel microbial activity. Simultaneously this causes a more even nutrient depletion in the rhizosphere, facilitating microbial mining for nutrients via SOM mineralization. Second, root morphology is a vital driver affecting soil properties such as aggregation (Dorodnikov et al., 2009). Higher planting densities enhanced the proportion of smaller aggregates size classes $(<250 \mu \mathrm{m})$, which favor microbial and enzymatic activities due to the better supply of water and substrates (Kumar et al., 2017).

In addition to plant intraspecific competition, higher planting density might intensify the plant-microbial competition for nutrients, and thus retard microbial activity for SOM decomposition due to the rapid depletion of available nutrients by root uptake (Dormaar, 1990; Kuzyakov, 2002). Hence, the nutrient competition hypothesis is expected as one explanation for the unaffected SOM-C and N mineralization rates at higher planting densities (compared to the single density; Dijkstra et al., 2010; Pausch et al., 2013; Yin et al., 2018). This is also supported by the declining specific SOM-C and N mineralization rates with increasing densities due to intraspecific competition, yet not always significant (the SOM-derived $\mathrm{CO}_{2}$ efflux and gross $\mathrm{N}$ mineralization rate per unit of root length; Figure S5 and Table S2). However, since both microbial biomass and the activities of the $\mathrm{N}$ acquiring enzyme (i.e., L-leucine aminopeptidase) were similar among three planting densities (Table 2 and Table S2; Kumar et al., 2017), we cannot explicitly confirm the negative effects of nutrient competition on SOM mineralization. This is possibly attributed to the relatively high initial nutrients contents in arable soils compared to those in natural ecosystems. Despite the increased nutrient-competition between plant and microorganisms at higher planting densities, the extent to which the soil nutrient was depleted may not cause microorganisms to suffer from strong $\mathrm{N}$ limitation, according to the threshold elemental ratios for microorganisms (Kaiser, Franklin, Dieckmann, \& Richter, 2014; Moorhead, Lashermes, \& Sinsabaugh, 2012). Therefore, in situ tracer labeling (i.e., ${ }^{15} \mathrm{~N}$ ) for reliably quantifying the plantmicrobial competition for nutrients is needed (Kuzyakov \& Xu, 2013). Future work also needs to encompass other competitive and mutualistic interactions such as $\mathrm{N}$ fixation by rhizobia and mycorrhizal fungi.

In conclusion, our study provides in situ evidence for the predominant mechanisms of rhizosphere effects on soil $\mathrm{C}$ and $\mathrm{N}$ mineralization in an arable soil under field conditions. Root-mediated increase of microbial activity and nutrient mining from SOM is a major mechanism driving $\mathrm{C}$ and $\mathrm{N}$ cycling as indicated by the coupled SOM-C and $\mathrm{N}$
FIGURE 4 Linear relationship of SOM-derived $\mathrm{CO}_{2}$ efflux (a) and gross $\mathrm{N}$ mineralization (GNM) (b) with specific root length $(n=12)$. Each dot represents the individual replicate of the single (P), double (DP), and triple (TP) densities across three growth stages [Colour figure can be viewed at wileyonlinelibrary.com]
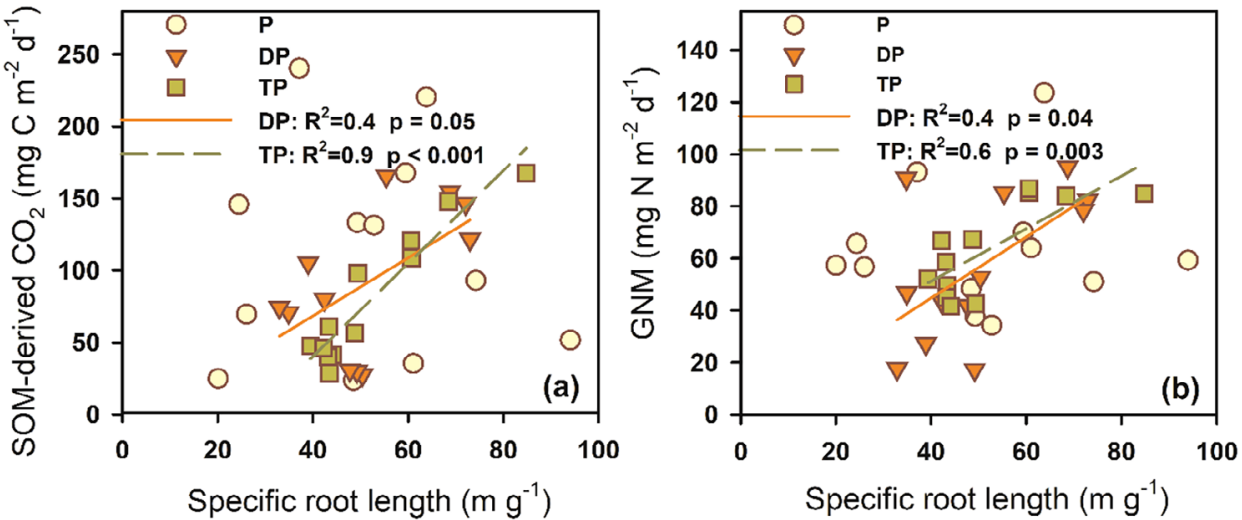


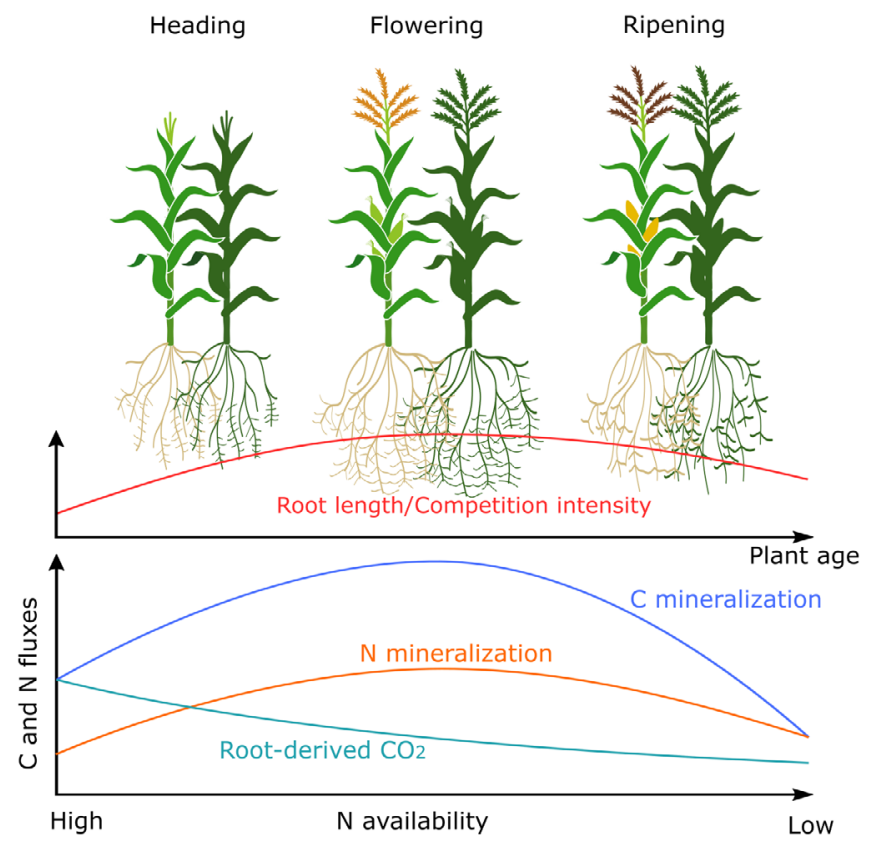

FIGURE 5 The changes in root morphological trait and belowground intraspecific intensity from maize heading to ripening stages, and the dynamics of soil $\mathrm{C}$ and $\mathrm{N}$ fluxes across all level of planting densities [Colour figure can be viewed at wileyonlinelibrary.com]

mineralization throughout plant growth. The mineralization rates of $\mathrm{C}$ relative to $\mathrm{N}$ are regulated by microbial $\mathrm{N}$ availability and demand. Owing to higher intraspecific competition at flowering, maize adjusted its root morphology for competing nutrients by the occupation of new soil volume, and strongly impact SOM mineralization. Instead of root mass per se, SOM-C and $\mathrm{N}$ mineralization under higher planting densities were more related to root morphology (i.e., specific root length) (Figure 5). Consequently, due to an elevated nutrient demand under plant-plant and/or plant-microbial competition, root adaptation traits and soil nutrients availability play an important role in modulating the activity and processes of microbial $\mathrm{C}$ and $\mathrm{N}$ cycling.

\section{ACKNOWLEDGMENTS}

We gratefully acknowledge Karin Schmidt, Anita Kriegel, Susann Enzmann, and Ingrid Ostermeyer for their careful help with laboratory and fieldwork. We thank the Laboratory for Radioisotopes (LARI) and Centre for Stable Isotope Research and Analysis (KOSI) of the University of Göttingen. We would also like to thank China Scholarship Council for the fellowship for Yue Sun and Huadong Zang, and the DAAD scholarship award to Amit Kumar. We thank Amanda Troxell and Jiarui Gan for the suggestions on manuscript. The authors would like to thank the editor and two reviewers for constructive comments and suggestions.

\section{CONFLICT OF INTERESTS}

The authors declare that the research was conducted in the absence of any commercial or financial relationships that could be construed as a potential conflict of interest.

\section{ORCID}

Yue Sun (D) https://orcid.org/0000-0002-2207-6423

\section{REFERENCES}

Adler, P. B., Smull, D., Beard, K. H., Choi, R. T., Furniss, T., Kulmatiski, A., ... Veblen, K. E. (2018). Competition and coexistence in plant communities: Intraspecific competition is stronger than interspecific competition. Ecology Letters, 21, 1319-1329.

Aerts, R. (1999). Interspecific competition in natural plant communities: Mechanisms, trade-offs and plant-soil feedbacks. Journal of Experimental Botany, 50, 29-37.

Amos, B., \& Walters, D. T. (2006). Maize root biomass and net rhizodeposited carbon. Soil Science Society of America Journal, 70, 1489-1503.

Bardgett, R. D., Bowman, W. D., Kaufmann, R., \& Schmidt, S. K. (2005). A temporal approach to linking aboveground and belowground ecology. Trends in Ecology and Evolution, 20, 634-641.

Bengtson, P., Barker, J., \& Grayston, S. J. (2012). Evidence of a strong coupling between root exudation, $\mathrm{C}$ and $\mathrm{N}$ availability, and stimulated SOM decomposition caused by rhizosphere priming effects. Ecology and Evolution, 2, 1843-1852.

Berger, B. M. (1999). Factors influencing transformation rates and formation of products of phenylurea herbicides in soil. Journal of Agricultural and Food Chemistry, 47, 3389-3396.

Blagodatskaya, E., Khomyakov, N., Myachina, O., Bogomolova, I., Blagodatsky, S., \& Kuzyakov, Y. (2014). Microbial interactions affect sources of priming induced by cellulose. Soil Biology and Biochemistry, 74, 39-49.

Blagodatskaya, E., Yuyukina, T., Blagodatsky, S., \& Kuzyakov, Y. (2011). Turnover of soil organic matter and of microbial biomass under C3-C4 vegetation change: Consideration of $13 \mathrm{C}$ fractionation and preferential substrate utilization. Soil Biology and Biochemistry, 43, 159-166.

Callaway, R. M., Brooker, R. W., Choler, P., Kikvidze, Z., Lortie, C. J., Michalet, R., ... Cook, B. J. (2002). Positive interactions among alpine plants increase with stress. Nature, 417, 844-848.

Chen, Y., Palta, J. A., Wu, P., \& Siddique, K. H. M. (2019). Crop root systems and rhizosphere interactions. Plant and Soil, 439, 1-5.

Cheng, W., Johnson, D. W., \& Fu, S. (2003). Rhizosphere effects on decomposition. Soil Science Society of America Journal, 67, 1418-1427.

Cheng, W., \& Kuzyakov, Y. (2005). Root effects on soil organic matter decomposition. Agronomy, 48, 119-144.

Cheng, W., Parton, W. J., Gonzalez-Meler, M. A., Phillips, R., Asao, S., Mcnickle, G. G., ... Jastrow, J. D. (2014). Synthesis and modeling perspectives of rhizosphere priming. New Phytologist, 201, 31-44.

Colom, S. M., \& Baucom, R. S. (2019). Belowground competition can influence the evolution of root traits. The American Naturalist, 195, 577-590.

Craine, J. M., Morrow, C., \& Fierer, N. (2007). Microbial nitrogen limitation increases decomposition. Ecology, 88, 2105-2113.

Craine, J. M., Wedin, D. A., Chapin, F. S., \& Reich, P. B. (2003). Relationship between the structure of root systems and resource use for 11 north american grassland plants. Plant Ecology, 165, 85-100.

Davidson, E. a., Hart, S. C., Shanks, C. a., \& Firestone, M. K. (1991). Measuring gross nitrogen mineralization, immobilization, and nitrification by $\mathrm{N}-15$ isotopic pool dilution in intact soil cores. Journal of Soil Science, 42, 335-349.

Dijkstra, F. A., Bader, N. E., Johnson, D. W., \& Cheng, W. (2009). Does accelerated soil organic matter decomposition in the presence of plants increase plant $\mathrm{N}$ availability? Soil Biology and Biochemistry, 41, 1080-1087.

Dijkstra, F. A., \& Cheng, W. (2007). Interactions between soil and tree roots accelerate long-term soil carbon decomposition. Ecology Letters, 10, 1046-1053. 
Dijkstra, F. A., Cheng, W., \& Johnson, D. W. (2006). Plant biomass influences rhizosphere priming effects on soil organic matter decomposition in two differently managed soils. Soil Biology and Biochemistry, 38, 2519-2526.

Dijkstra, F. A., Morgan, J. A., Blumenthal, D., \& Follett, R. F. (2010). Water limitation and plant inter-specific competition reduce rhizosphereinduced $\mathrm{C}$ decomposition and plant $\mathrm{N}$ uptake. Soil Biology and Biochemistry, 42, 1073-1082.

Dormaar, J. F. (1990). Effect of active roots on the decomposition of soil organic materials. Biology and Fertility of Soils, 10, 121-126.

Dorodnikov, M., Blagodatskaya, E., Blagodatsky, S., Marhan, S., Fangmeier, A., \& Kuzyakov, Y. (2009). Stimulation of microbial extracellular enzyme activities by elevated $\mathrm{CO} 2$ depends on soil aggregate size. Global Change Biology, 15, 1603-1614.

Drinkwater, L. E., \& Snapp, S. (2007). Understanding and managing the rhizosphere in agroecosystems. In: Cardon, ZG, Whitbeck, JL (eds), The rhizosphere: an ecological perspective. Elsevier Academic Press, London, UK, pp 127-153.

Ehtesham, E., \& Bengtson, P. (2017). Decoupling of soil carbon and nitrogen turnover partly explains increased net ecosystem production in response to nitrogen fertilization. Scientific Reports, 7, 46286.

Fan, F., Zhang, F., \& Lu, Y. (2011). Linking plant identity and interspecific competition to soil nitrogen cycling through ammonia oxidizer communities. Soil Biology and Biochemistry, 43, 46-54.

FAO (2006) World reference base for soil resources 2006: a framework for international classification, correlation and communication.

Finzi, A. C., Abramoff, R. Z., Spiller, K. S., Brzostek, E. R., Darby, B. A., Kramer, M. A., \& Phillips, R. P. (2015). Rhizosphere processes are quantitatively important components of terrestrial carbon and nutrient cycles. Global Change Biology, 21, 2082-2094.

Francis, C., Lieblein, G., Gliessman, S., Breland, T. A., Creamer, N., Harwood, R., ... Poincelot, R. (2003). Agroecology: The ecology of food systems. Journal of Sustainable Agriculture, 22, 99-118.

Frank, D. A., \& Groffman, P. M. (2009). Plant rhizospheric N processes: what we don't know and why we should care. Ecology, 90, 1512-1519.

Gregory, P. J., \& Atwell, B. J. (1991). The fate of carbon in pulse-labelled crops of barley and wheat. Plant and Soil, 136, 205-213.

Hagedorn, F., Spinnler, D., \& Siegwolf, R. (2003). Increased N deposition retards mineralization of old soil organic matter. Soil Biology and Biochemistry, 35, 1683-1692.

Hessen, D. O., Ågren, G. I., Anderson, T. R., Elser, J. J., Peter, C., Hessen, D. A. G. O., ... Ruiter, P. C. D. E. (2004). Carbon sequestration in ecosystems: The role of stoichiometry. Ecology, 85, 1179-1192.

Huo, C., Luo, Y., \& Cheng, W. (2017). Rhizosphere priming effect: A metaanalysis. Soil Biology and Biochemistry, 111, 78-84.

Jenkinson, D. S., \& Rayner, J. H. (1977). The turnover of soil organic matter in some of the rothamsted classical experiments. Soil Science, 123, 298-305.

Joergensen, R. G., \& Mueller, T. (1996). The fumigation-extraction method to estimate soil microbial biomass: Calibration of the kEN value. Soil Biology and Biochemistry, 28, 33-37.

Kaiser, C., Franklin, O., Dieckmann, U., \& Richter, A. (2014). Microbial community dynamics alleviate stoichiometric constraints during litter decay. Ecology Letters, 17, 680-690.

Kumar, A., Dorodnikov, M., Splettstößer, T., Kuzyakov, Y., \& Pausch, J. (2017). Effects of maize roots on aggregate stability and enzyme activities in soil. Geoderma, 306, 50-57.

Kumar, A., Kuzyakov, Y., \& Pausch, J. (2016). Maize rhizosphere priming: field estimates using C-13 natural abundance. Plant and Soil, 409, 87-97.

Kumar, A., Shahbaz, M., Blagodatskaya, E., Kuzyakov, Y., \& Pausch, J. (2018). Maize phenology alters the distribution of enzyme activities in soil: Field estimates. Applied Soil Ecology, 125, 233-239.
Kumar, A., van Duijnen, R., Delory, B. M., Reichel, R., Brüggemann, N., \& Temperton, V. M. (2020). Barley shoot biomass responds strongly to $\mathrm{N}: \mathrm{P}$ stoichiometry and intraspecific competition, whereas roots only alter their foraging. Plant and Soil, 453, 515-528.

Kunstler, G., Falster, D., Coomes, D. A., Hui, F., Kooyman, R. M., Laughlin, D. C., ... Westoby, M. (2016). Plant functional traits have globally consistent effects on competition. Nature, 529, 204-207.

Kuzyakov, Y. (2002). Review: Factors affecting rhizosphere priming effects. Journal of Plant Nutrition and Soil Science-Zeitschrift Fur Pflanzenernahrung Und Bodenkunde, 165, 382-396.

Kuzyakov, Y., Biryukova, O. V., Kuznetzova, T. V., Molter, K., Kandeler, E., \& Stahr, K. (2002). Carbon partitioning in plant and soil, carbon dioxide fluxes and enzyme activities as affected by cutting ryegrass. Biology and Fertility of Soils, 35, 348-358.

Kuzyakov, Y., \& Xu, X. (2013). Competition between roots and microorganisms for nitrogen: Mechanisms and ecological relevance. New Phytologist, 198, 656-669.

Li, H., Wang, X., Brooker, R. W., Rengel, Z., Zhang, F., Davies, W. J., \& Shen, J. (2019). Root competition resulting from spatial variation in nutrient distribution elicits decreasing maize yield at high planting density. Plant and Soil, 439, 219-232.

Li, X. G., Jia, B., Lv, J., Ma, Q., Kuzyakov, Y., \& Li, F. m. (2017). Nitrogen fertilization decreases the decomposition of soil organic matter and plant residues in planted soils. Soil Biology and Biochemistry, 112, 47-55.

Loecke, T. D., Cambardella, C. A., \& Liebman, M. (2012). Synchrony of net nitrogen mineralization and maize nitrogen uptake following applications of composted and fresh swine manure in the Midwest U.S. Nutrient Cycling in Agroecosystems, 93, 65-74.

Ma, Z., Guo, D., Xu, X., Lu, M., Bardgett, R. D., Eissenstat, D. M., ... Hedin, L. O. (2018). Evolutionary history resolves global organization of root functional traits. Nature, 555, 94-97.

Mason-Jones, K., Schmücker, N., \& Kuzyakov, Y. (2018). Contrasting effects of organic and mineral nitrogen challenge the N-Mining Hypothesis for soil organic matter priming. Soil Biology and Biochemistry, 124, 38-46.

BBCH Monograph (2001). Growth Stages of Mono- and Di-cotyledonous Plants. 2nd Edition. Meier, U. (ed.), Federal Biological Research Centre for Agriculture and Forestry, Berlin and Braunschweig, Germany, $158 \mathrm{pp}$.

Miller, J. B., \& Tans, P. P. (2003). Calculating isotopic fractionation from atmospheric measurements at various scales. Tellus, Series B: Chemical and Physical Meteorology, 55, 207-214.

Moorhead, D. L., Lashermes, G., \& Sinsabaugh, R. L. (2012). A theoretical model of $\mathrm{C}$ - and $\mathrm{N}$-acquiring exoenzyme activities, which balances microbial demands during decomposition. Soil Biology and Biochemistry, 53, 133-141.

Moreau, D., Pivato, B., Bru, D., Busset, H., Deau, F., Faivre, C., ... Mougel, C. (2015). Plant traits related to nitrogen uptake influence plant-microbe competition. Ecology, 96, 2300-2310.

Murphy, C. J., Baggs, E. M., Morley, N., Wall, D. P., \& Paterson, E. (2015). Rhizosphere priming can promote mobilisation of $\mathrm{N}$-rich compounds from soil organic matter. Soil Biology and Biochemistry, 81, 236-243.

Murphy, D. V., Recous, S., Stockdale, E. A., Fillery, I. R. P., Jensen, L. S., Hatch, D. J., \& Goulding, K. W. T. (2003). Gross nitrogen fluxes in soil: Theory, measurement and application of $15 \mathrm{~N}$ pool dilution techniques. Advances in Agronomy, 79, e118.

Nguyen, C. (2003). Rhizodeposition of organic C by plants: Mechanisms and controls. Agronomie, 23, 375-396.

Nord, E. A., \& Lynch, J. P. (2009). Plant phenology: A critical controller of soil resource acquisition. Journal of Experimental Botany, 60, 1927-1937.

Osterholz, W. R., Rinot, O., Liebman, M., \& Castellano, M. J. (2017). Can mineralization of soil organic nitrogen meet maize nitrogen demand? Plant and Soil, 415, 73-84. 
Paterson, E. (2003). Importance of rhizodeposition in the coupling of plant \randmicrobial productivity. European Jounal of Soil Science, 54, 741-750.

Pausch, J., \& Kuzyakov, Y. (2018). Carbon input by roots into the soil: Quantification of rhizodeposition from root to ecosystem scale. Global Change Biology, 24, 1-12.

Pausch, J., Loeppmann, S., Kühnel, A., Forbush, K., Kuzyakov, Y., \& Cheng, W. (2016). Rhizosphere priming of barley with and without root hairs. Soil Biology and Biochemistry, 100, 74-82.

Pausch, J., Zhu, B., Kuzyakov, Y., \& Cheng, W. (2013). Plant inter-species effects on rhizosphere priming of soil organic matter decomposition. Soil Biology and Biochemistry, 57, 91-99.

Phillips, D. L., \& Gregg, J. W. (2001). Uncertainty in source partitioning using stable isotopes. Oecologia, 127, 171-179.

Phillips, R. P., Finzi, A. C., \& Bernhardt, E. S. (2011). Enhanced root exudation induces microbial feedbacks to $\mathrm{N}$ cycling in a pine forest under long-term CO2 fumigation. Ecology Letters, 14, 187-194.

Price, P. B., \& Sowers, T. (2004). Temperature dependence of metabolic rates for microbial growth, maintenance, and survival. Proceedings of the National Academy of Sciences of the United States of America, 101, 4631-4636.

Sanaullah, M., Chabbi, A., Rumpel, C., \& Kuzyakov, Y. (2012). Carbon allocation in grassland communities under drought stress followed by $14 \mathrm{C}$ pulse labeling. Soil Biology and Biochemistry, 55, 132-139.

Schenk, H. J. (2006). Root competition: Beyond resource depletion. Journal of Ecology, 94, 725-739.

Schofield, E. J., Brooker, R. W., Rowntree, J. K., Price, E. A. C., Brearley, F. Q., \& Paterson, E. (2019). Plant-plant competition influences temporal dynamism of soil microbial enzyme activity. Soil Biology and Biochemistry, 139, 107615.

Shahzad, T., Chenu, C., Genet, P., Barot, S., Perveen, N., Mougin, C., \& Fontaine, S. (2015). Contribution of exudates, arbuscular mycorrhizal fungi and litter depositions to the rhizosphere priming effect induced by grassland species. Soil Biology and Biochemistry, 80, 146-155.

Shields, J. A., Paul, E. A., Lowe, W. E., \& Parkinson, D. (1973). Turnover of microbial tissue in soil under field conditions. Soil Biology and Biochemistry, 5, 753-764.

Spiertz, J. H. J. (2010). Nitrogen, sustainable agriculture and food security. A review. Agronomy for Sustainable Development, 30, 43-55.

Sun, L., Ataka, M., Han, M., Han, Y., Gan, D., Xu, T., Zhu, B., \& Guo, Y. (2020). Root exudation as a major competitive fine-root functional trait of 18 coexisting species in a subtropical forest. New Phytologist. https://doi.org/10.1111/nph.16865.

Sun, Y., Schleuss, P., Pausch, J., Xu, X., \& Kuzyakov, Y. (2018). Nitrogen pools and cycles in Tibetan Kobresia pastures depending on grazing. Biology and Fertility of Soils, 54, 569-581.

Tiessen, H., Cuevas, E., \& Chacon, P. (1994). The role of soil organic matter in sustaining soil fertility. Nature, 371, 783-785.

Tilman, D. (1990). Mechanisms of plant competition for nutrients: the element of a predicitive theory of competition. In J. B. Grace, \& D. Tilman (Eds.), Perspectives on plant competition (pp. 117-141). San Diego: Academic Press.

Valverde-Barrantes, O. J., Smemo, K. A., \& Blackwood, C. B. (2015). Fine root morphology is phylogenetically structured, but nitrogen is related to the plant economics spectrum in temperate trees. Functional Ecology, 29, 796-807.

Vance, E. D., Brookes, P. C., \& Jenkinson, D. S. (1987). An extraction method for measuring soil microbial biomass C. Soil Biology and Biochemistry, 19, 703-707.

Wang, H., Boutton, T. W., Xu, W., Hu, G., Jiang, P., \& Bai, E. (2015) Quality of fresh organic matter affects priming of soil organic matter and substrate utilization patterns of microbes. Scientific Reports, 5, 1-13.

Wang, M., Yang, J., Gao, H., Xu, W., Dong, M., \& Shen, G. (2020). Forest ecology and management interspecific plant competition increases soil labile organic carbon and nitrogen contents. Forest Ecology and Management, 462, 117991.

Wen, Z., Li, H., Shen, J., \& Rengel, Z. (2017). Maize responds to low shoot $P$ concentration by altering root morphology rather than increasing root exudation. Plant and Soil, 416, 377-389.

Werth, M., \& Kuzyakov, Y. (2010). 13C fractionation at the root-microorganisms-soil interface: A review and outlook for partitioning studies. Soil Biology and Biochemistry, 42, 1372-1384.

Yin, L., Dijkstra, F. A., Wang, P., Zhu, B., \& Cheng, W. (2018). Rhizosphere priming effects on soil carbon and nitrogen dynamics among tree species with and without intraspecific competition. New Phytologist, 218 , 1036-1048.

Zhu, B., \& Cheng, W. (2011a). 13C isotope fractionation during rhizosphere respiration of C3 and C4 plants. Plant and Soil, 342, 277-287.

Zhu, B., \& Cheng, W. (2011b). Rhizosphere priming effect increases the temperature sensitivity of soil organic matter decomposition. Global Change Biology, 17, 2172-2183.

Zhu, B., \& Cheng, W. (2012). Nodulated soybean enhances rhizosphere priming effects on soil organic matter decomposition more than nonnodulated soybean. Soil Biology and Biochemistry, 51, 56-65.

Zhu, B., \& Cheng, W. (2013). Impacts of drying-wetting cycles on rhizosphere respiration and soil organic matter decomposition. Soil Biology and Biochemistry, 63, 89-96.

Zhu, B., Gutknecht, J. L. M., Herman, D. J., Keck, D. C., Firestone, M. K., \& Cheng, W. (2014). Rhizosphere priming effects on soil carbon and nitrogen mineralization. Soil Biology and Biochemistry, 76, 183-192.

Zhu, Z., Ge, T., Liu, S., Hu, Y., Ye, R., Xiao, M., ... Wu, J. (2018). Rice rhizodeposits affect organic matter priming in paddy soil: The role of $\mathrm{N}$ fertilization and plant growth for enzyme activities, $\mathrm{CO} 2$ and $\mathrm{CH} 4$ emissions. Soil Biology and Biochemistry, 116, 369-377.

\section{SUPPORTING INFORMATION}

Additional supporting information may be found online in the Supporting Information section at the end of this article.

How to cite this article: Sun $\mathrm{Y}$, Zang H, Splettstößer T, et al. Plant intraspecific competition and growth stage alter carbon and nitrogen mineralization in the rhizosphere. Plant Cell Environ. 2020;1-12. https://doi.org/10.1111/pce.13945 